International Journal of Biology, Pharmacy and Allied Sciences (IJBPAS) 'A Bridgs Betueen Caboratory and QRendo'

\author{
WwW.ijbpas.com
}

\title{
IMPACT OF GRADED DIETARY PROTEIN ON HAEMATOOGICAL PARAMETERS OF GENETICALLY IMPROVED FARMED TILAPIA (GIFT)
}

\section{KOUSAR A, NAEEM M* AND MASUD S}

Institute of Pure and Applied Biology, Bahauddin Zakariya University, Multan, Pakistan *For Correspodence: dr naeembzu@yahoo.com; (Tel (+92)-333-7878881) (Fax (+92)-61-9210098) Received 19 ${ }^{\text {th }}$ March 2019; Revised $18^{\text {th }}$ April 2019; Accepted 19 ${ }^{\text {th }}$ May 2019; Available online $1^{\text {st }}$ Nov. 2019 https://doi.org/10.31032/IJBPAS/2019/8.11.4856

\section{ABSTRACT}

The objective of the present study was to evaluate the impact of graded levels of plant protein diets $(15 \%, 20 \%$ and $25 \%)$ on haematological profile of mono sex (male) Genetically Improved Farmed Tilapia (GIFT), a developed strain of Nile tilapia (Oreochromis niloticus). Three treatment groups $(\mathrm{T} 1=15 \%, \mathrm{~T} 2=20 \%$ and $\mathrm{T} 3=25 \%)$ were formed and experiment was carried out in duplicate. Five days old GIFT tilapia fingerlings of mean weight $0.24 \pm 0.03(\mathrm{~g})$ and length $2.01 \pm 0.27(\mathrm{~cm})$ were collected, acclimatized for two weeks, and transferred to hapas $(8 \times 6 \times 3 \mathrm{ft})$ at random. Fingerlings were fed @ $10 \%$ during acclimatization period and $5 \%$ up to the end of experiment. At the end of 90 days feeding trial, ten fishes were randomly selected from each treatment hapa for the estimation of haematology. Haematological parameters viz. WBCs, LYM, MON, GRA, RBCs, HGB, HCT, MCV, MCH, MCHC, PLT, MPV were studied. The RBCs values in T1, T2 and T3 were $0.93 \pm 0.30,1.40 \pm 0.48$ and $1.47 \pm 0.16\left(10^{6} / \mu \mathrm{L}\right)$ respectively. The WBCs values in $\mathrm{T} 1, \mathrm{~T} 2$ and $\mathrm{T} 3$ were calculated as $55.51 \pm 10.25,59.29 \pm 12.86$ and $104.32 \pm 18.82\left(10^{3} / \mu 1\right)$ respectively. In $\mathrm{T} 1, \mathrm{~T} 2$ and $\mathrm{T} 3$ the platelets count was estimated as $196.04 \pm 80.31,225.87 \pm 59.32$ and $290.00 \pm 186.00$ respectively. Statistical relationship was studied applying linear regression analysis.RBCs, WBCs exhibited non-significant correlation against total length and weight in all groups. While, platelet count yielded non-significant correlation in T1, T2 and T3 with weight and length except for T2 which was found least significant against length. T3 fish fed at 25\% $\mathrm{CP}$ exhibited more WBCs, RBCs and their indices with in the range as compared to $\mathrm{T} 1$ and T2 fish. Thus, protein diet (25\%) is cost effective as well as keep the fish in good health condition.

Keywords: Haematological profile, GIFT, Fingerling, Hapas, Graded levels of protein, Fish size 


\section{INTRODUCTION}

Fish nutrition and feeding is one of the major requirements for sustainable aquaculture production. In fish culture, the most expensive component is feed. It represents about $30 \%$ to $60 \%$ of the total variable cost [1]. Traditionally, in aquaculture, the major source of protein used in formulated feeds is fish meal because of its good quality protein, high protein contents, palatability and balanced amino acid profile $[2,3,4]$. However, fish meal supplies and prices have witnessed significant fluctuations [2]. The health status of living organisms of animal origin can be revealed by blood parameters. While, the level of infection and immune response status is a reflection of leukocytes count. [5]. The nutrients intake through feed represents the development of hematocrit component. So, it is of prime importance to maintain a balance, in the optimum quantities, of different nutrients in formulating quality feed. For blood cell formation, requirement of protein is vital and its supply is dependant on the optimum combination of amino acids [4]. Utilization of new feed combinations to provide essential nutrients may serve as positive health indicator and reduction in utilization of fish meal percentage in feeds [6].

The haematological characteristics play an integral part in the evaluation of fish health status [7]. The main factors responsible for alteration in haematological profile of fish include sex, species, stress, diet composition, metabolic adaptation and variation in fish physiology [2, 8, 9]. Haematological analysis is considered a valuable tool for monitoring physiological responses, assessment of diet composition, nutritional status and fish health [10].

Blood, constituting the most abundant body fluid, represents physiological condition of an organism including fish. Valuable information can be obtained by the analysis of blood cells regarding fish diseases [11]. The blood of fish is similar with other vertebrates as it consists of plasma comprising of $97 \%$ water, electrolytes, minerals, hormones and cellular constituents (WBCs, RBCs) and platelets [3].

According to $[12,13]$ analysis of haematological and biochemical indices act as useful tools in the assessment of performance, viability and health status of farmed fish and animals. Analysisof haematological profile provides reflection of physiological responsiveness of animals to their internal and external environments. So, external environmental fluctuations may lead to blood dysfunction and severely influence the physiological activities like 
metabolism, resistance to disease and breeding performance [14].

Some studies have investigated the influence of variations in quality and composition of feedon the blood parameters indices of fish $[6,7,15,16,17]$. A wide variety of nutritional and antinutritional factors in the feed ingredients could be a cause of haematological profile variations [18]. These parameters are also closely related to the environmental and biological factors [19]. The good health status of fish is the main element for theirwelfare thus it is of great importance [20]. Therefore, the objective of the present study was to evaluate the impact of plant protein diets of three feeding regimes $(15 \%, 20 \%$ and $25 \%$ crude protein) as well as body size of treated fish on the haematological profile of Genetically Improved Farmed Tilapia.

\section{MATERIALS AND METHODS}

\section{Feed formulation}

Feed formulation of three experimental diets incorporated with graded levels of crude protein $(15 \%, 20 \%$ and $25 \%)$ using locally available cheaper feed contents i.e. sunflower meal, canola meal, sarson meal, soya bean meal, wheat bran, rice polish was carried out in Fish Feed Laboratory, Institute of Pure and Applied Biology, Bahauddin Zakariya University, Multan, Pakistan.

\section{Experiment site}

Five days old fingerlings of monosex (male) Genetically Improved Farmed Tilapia (GIFT), a strain of Nile tilapia (Oreochromis niloticus), to evaluate the influence of graded levels of protein diets haematological profile, were collected from the Fish Farm Facilities, Tawakkal Tilapia Hatchery, Tawakkal Nagar $\left(30^{\circ} 11^{\prime} 27^{\prime \prime} \mathrm{N}\right.$, $71^{\circ} 15^{\prime} 4^{\prime \prime}$ E), 18 Km Jhang Road, Muzaffar Garh, Punjab, Pakistan. Fingerlings were acclimatized for two weeks andfish were fed @10\% body weight. While, through out the 90 days feeding trial, fishwere fed @ 5\% body weight. Experiment was carried out in hapas $(8 \times 6 \times 3 \mathrm{ft})$ in duplicate from June to August 2017. Fish were fed twice daily between 8:00 - 9:00 am and 7:00 8:00 pm.

\section{Sampling}

At the end of 90 days feeding trial, ten fish from each treatment hapa (T1, T2, T3) were selected randomly. All fish samples were anesthetized using MS-222 (buffered solution; $30 \mathrm{mg} / \mathrm{L}$ ) in order to bleed the fish samples alive. Prior to blood sampling, wet body weight (W) and total length (TL) were also recorded. Blood samples were collected directly by puncturing fish heart using $1 \mathrm{ml}$ hypodermic syringe (21 Gauge). EDTA (ethylene diamine tetra acetic acid, an anticoagulant) vials were used for collection of blood. 


\section{Determination of haematological profile}

Blood samples were rapidly subjected to haematological laboratory for the determination of haematological analysis. Blood cell and their various indices were estimated in all the treatment groups. Indices of RBCs includes haemoglobin, hematocrit, mean corpuscular volume, mean corpuscular haemoglobin and mean corpuscular haemoglobin concentration. The types of WBCs (White blood cells) comprise of LYM (Lymphocytes), GRA (Granulocytes) and MON (Monocytes), platelets (PLT) and mean platelets volume (MPV) were also estimated in all the treated groups using Mythic 18 automatic heamatology analyzer, Orphee, Switzerland.

\section{Data analysis}

Descriptive statistics for each haematological parameter was expressed as Mean \pm Standard Deviation. All the results, based on randomized design, were subjected to linear regression, to calculate the relationship of total length (TL) versus blood parameters and wet body weight (W) versus blood parameters using MS Excel. [6].

\section{RESULTS}

Means, Standard deviations and ranges of the RBCs, WBCs and platelet count and their indices in studied GIFT under the influence of graded levels of protein in T1,
T2 and T3 fed at 15\%, 20\% and 25\% CP respectively are summarized in Table 1. The RBCs values in $\mathrm{T} 1, \mathrm{~T} 2$ and $\mathrm{T} 3$ were $0.93 \pm 0.30, \quad 1.40 \pm 0.48$ and $1.47 \pm 0.16$ $(106 / \mu \mathrm{L})$ respectively. The order of RBCs count was $\mathrm{T} 3>\mathrm{T} 2>\mathrm{T} 1$. The WBCs values in $\mathrm{T} 1, \mathrm{~T} 2$ and $\mathrm{T} 3$ were calculated as $55.51 \pm 10.25, \quad 59.29 \pm 12.86 \quad$ and $104.32 \pm 18.82\left(10^{3} / \mu 1\right)$ respectively. In $\mathrm{T} 1$, $\mathrm{T} 2$ and T3, the platelets count was $196.04 \pm 80.31, \quad 225.87 \pm 59.32 \quad \&$ $290.00 \pm 186.00 \quad$ respectively. The observation order for platelets count was found as $\mathrm{T} 3>\mathrm{T} 2>\mathrm{T} 1$.

\section{Relationship between haematological parameters and body size}

Linear regression was applied to sudy the correlation ofhaematological parameters with total length (TL, cm) and wet weight $(\mathrm{W}, \mathrm{g})$ with respect to three different feeds of graded protein levels $(15 \%, 20 \%$ and $25 \%$ ) and results are presented in Table 2 and 3 respectively.

Red blood cells (RBCs, $10^{3} / \mu \mathrm{L}$ ) on plotting against TL (cm) and W (g) exhibited nonsignificant correlation in all the three groups (T1, T2 and T3). A highly significant correlation $(\mathrm{r}=0.881)$ between HGB (g/dl) and TL (cm) was observed in T3 $(\mathrm{p}<0.001)$. While, T1 and T2 showed non- significant values for HGB. Similarly, HGB exhibited least significant relationship in $\mathrm{T} 3(\mathrm{r}=0.687, \mathrm{P}<0.05)$ against wet body 
weight (Table 3), while non-significant relations were observed in $\mathrm{T} 1$ and $\mathrm{T} 2$ (Table 2 and 3). MCV relationship denoted non-significant values in $\mathrm{T} 1, \mathrm{~T} 2$ and $\mathrm{T} 3$ with TL (cm) and W (g) (Table2 and 3). $\mathrm{MCH}$ expressed least significant correlation in $\mathrm{T} 1(\mathrm{r}=0.696, \mathrm{P}<0.05)$ when analyzed against both total length (Table 2) and Wet body weight $(\mathrm{r}=0.668, \mathrm{P}<0.05)$ (Table 6.3). However, non-significant results were observed in both T2 and T3. MCHC values expressed non-significant relationships in T1, T2 and T3 with total length and wet body weight (Table 2 and 3 ).

A non-significant relation was found between white blood cells (WBCs, $10^{3} / \mu \mathrm{L}$ ) and total length (TL, cm) as well as with wet body weight in all the treated groups
T1, T2 and T3 (Table 2 and 3). Study of WBCs indices i.e. lymphocytes, monocytes and granulocytes indicated non-significant relationship in $\mathrm{T} 1, \mathrm{~T} 2$ and $\mathrm{T} 3$ when analyzed against both total length $(\mathrm{cm})$ and wet body weight $(\mathrm{g})$.

Regression between platelets and TL provided least significant results in $\mathrm{T} 2$ $(\mathrm{r}=0.703, \mathrm{P}<0.05)$ and non-significant in $\mathrm{T} 1$ and T3. Platelets correlation with wet weight exhibited non-significant relationship in $\mathrm{T} 1, \mathrm{~T} 2$ and $\mathrm{T} 3$. A nonsignificant correlation $(\mathrm{P}>0.05)$ was exhibited by MPV with both TL $(\mathrm{cm})$ and $\mathrm{W}(\mathrm{g})$ in $\mathrm{T} 1$ and $\mathrm{T} 3$ while least significant correlation was examined in $\mathrm{T} 2$ with total length (TL) but non-significant with wet weight (Table 2 and 3).

Table 1: The haematological parameters of Giftreared in hapas at graded levels of protein

\begin{tabular}{|c|c|c|c|c|c|c|}
\hline \multirow{3}{*}{$\begin{array}{l}\text { Hematological } \\
\text { Variables }\end{array}$} & \multicolumn{6}{|c|}{ Diet Variables } \\
\hline & \multicolumn{2}{|c|}{ T1 } & \multicolumn{2}{|c|}{ T2 } & \multicolumn{2}{|c|}{ T3 } \\
\hline & Mean \pm SD & Range & Mean \pm SD & Range & $\operatorname{Mean} \pm$ SD & Range \\
\hline WBC $\left(10^{3} / \mu \mathrm{L}\right)$ & $55.51 \pm 10.25$ & $42.80-72.00$ & $59.29 \pm 12.86$ & $42.50-99.40$ & $104.32 \pm 18.82$ & $84.50-136.30$ \\
\hline LYM $\left(10^{3} / \mu \mathrm{L}\right)$ & $61.99 \pm 18.84$ & $41.70-98.40$ & $69.54 \pm 18.06$ & $46.30-95.20$ & $85.23 \pm 11.14$ & $70.40-97.30$ \\
\hline $\operatorname{MON}\left(10^{3} / \mu \mathrm{L}\right)$ & $1.36 \pm 0.48$ & $41.70-98.40$ & $1.92 \pm 0.51$ & $1.50-2.90$ & $1.57 \pm 0.74$ & $0.80-2.80$ \\
\hline GRA $\left(10^{3} / \mu \mathrm{L}\right)$ & $7.70 \pm 6.76$ & $1.50-23.00$ & $4.41 \pm 1.29$ & $1.70-34.20$ & $12.70 \pm 10.22$ & $1.70-34.20$ \\
\hline LYM (\%) & $89.38 \pm 6.15$ & $78.00-97.40$ & $84.28 \pm 6.92$ & $70.60-91.90$ & $89.68 \pm 4.35$ & $82.30-96.70$ \\
\hline MON (\%) & $1.99 \pm 1.02$ & $0.70-3.80$ & $2.76 \pm 1.04$ & $1.00-4.30$ & $1.82 \pm 0.84$ & $0.80-3.40$ \\
\hline GRA (\%) & $8.63 \pm 5.28$ & $1.90-18.20$ & $13.08 \pm 6.18$ & $6.20-25.10$ & $8.22 \pm 3.96$ & $2.50-14.30$ \\
\hline $\mathrm{RBC}\left(10^{6} / \mu \mathrm{L}\right)$ & $0.93 \pm 0.30$ & $0.53-1.53$ & $1.40 \pm 0.48$ & $0.77-1.99$ & $1.47 \pm 0.16$ & $1.22-1.68$ \\
\hline HGB (g/dl) & $4.42 \pm 0.99$ & $2.70-6.50$ & $5.10 \pm 8.33$ & $2.60-7.90$ & $6.16 \pm 0.66$ & $5.70-7.90$ \\
\hline HCT (\%) & $11.65 \pm 8.71$ & $3.20-27.80$ & $15.94 \pm 8.33$ & $7.50-29.80$ & $24.07 \pm 3.93$ & $16.80-30.40$ \\
\hline $\operatorname{MCV}\left(\mu \mathrm{m}^{3}\right)$ & $150.01 \pm 30.36$ & $97.40-181.70$ & $140.75 \pm 46.73$ & $72.30-87.60$ & $119.20 \pm 61.14$ & $48.50-206.50$ \\
\hline МCH (pg) & $40.87 \pm 3.41$ & $34.90-47.90$ & $59.29 \pm 12.86$ & $42.50-83.00$ & $39.99 \pm 3.02$ & $35.70-45.00$ \\
\hline MCHC (g/dl) & $63.41 \pm 39.44$ & $21.10-128.10$ & $28.86 \pm 6.83$ & $22.40-40.10$ & $27.01 \pm 9.48$ & $13.70-42.30$ \\
\hline $\operatorname{PLT}\left(10^{3} / \mu \mathrm{L}\right)$ & $196.04 \pm 80.31$ & $\begin{array}{l}100.00- \\
357.00\end{array}$ & $225.87 \pm 59.32$ & $\begin{array}{l}162.70- \\
325.00\end{array}$ & $290.00 \pm 186.00$ & $\begin{array}{l}107.00- \\
653.00\end{array}$ \\
\hline $\operatorname{MPV}\left(\mu \mathrm{m}^{3}\right)$ & $5.71 \pm 0.43$ & $5.00-6.40$ & $6.17 \pm 0.79$ & $5.20-7.40$ & $5.85 \pm 0.53$ & $5.10-6.80$ \\
\hline
\end{tabular}


Table: 2 Statistical analysis of various haematological parameters in relation to total length $(\mathrm{cm})$ of GIFT reared at graded levels of protein in hapas

\begin{tabular}{|c|c|c|c|c|c|c|c|c|}
\hline \multirow[t]{2}{*}{ Equation } & \multirow{2}{*}{$\begin{array}{c}\text { Diet } \\
\text { Variables }\end{array}$} & \multicolumn{2}{|c|}{$\begin{array}{c}\text { Relationship } \\
\text { Parameters }\end{array}$} & \multirow[t]{2}{*}{$95 \%$ CI of a } & \multirow[t]{2}{*}{$95 \%$ CI of $b$} & \multirow{2}{*}{$\begin{array}{l}\text { Standard } \\
\text { error }\end{array}$} & \multirow[t]{2}{*}{$\mathbf{r}$} & \multirow[t]{2}{*}{$\mathbf{r}^{2}$} \\
\hline & & $\mathbf{A}$ & B & & & & & \\
\hline \multirow{3}{*}{$\mathbf{P L T}=\mathbf{a}+\mathbf{b} \mathbf{T L}$} & T1(15\%) & 307.5271 & -9.69 & 21.298-593.756 & $-34.048-14.659$ & 10.561 & $0.309 n s$ & 0.095 \\
\hline & T2(20\%) & 34.646 & 15.25 & $-126.557-195.849$ & $2.660-27.837$ & 5.459 & $0.703 *$ & 0.494 \\
\hline & T3(25\%) & 10.7563 & 23.51 & $-869.599-891.111$ & $-49.666-96.677$ & 31.731 & $0.253 n s$ & 0.064 \\
\hline \multirow{3}{*}{$\mathbf{W B C s}=\mathbf{a}+\mathbf{b} \mathbf{T L}$} & T1(15\%) & 0.5212 & 3.16 & $-18.195-59.237$ & $-0.135-6.453$ & 1.428 & $0.616 n s$ & 0.379 \\
\hline & T2(20\%) & 136.3074 & -2.55 & 69.528-203.086 & $-7.766-2.664$ & 2.261 & $0.370 \mathrm{~ns}$ & 0.137 \\
\hline & T3(25\%) & 117.4293 & -4.18 & $51.434-183.425$ & $-9.669-1.302$ & 2.379 & $0.528 n s$ & 0.279 \\
\hline \multirow{3}{*}{$\mathbf{R B C s}=\mathbf{a}+\mathbf{b} \mathbf{T L}$} & T1(15\%) & 0.7255 & 0.03 & $-1.011-1.011$ & $-0.119-0.176$ & 0.0641 & $0.155 n s$ & 0.024 \\
\hline & T2(20\%) & 1.4903 & $\begin{array}{l}-0.002 \\
\end{array}$ & $0.864-2.116$ & $-0.051-0.047$ & 0.021 & $0.032 n s$ & 0.001 \\
\hline & T3(25\%) & 1.5997 & -0.06 & $0.242-2.958$ & $-0.169-0.056$ & 0.049 & $0.379 n s$ & 0.143 \\
\hline \multirow{3}{*}{ HGB $=a+b$ TL } & T1(15\%) & 1.3976 & 0.32 & $-5.209-8.004$ & $-0.240-0.884$ & 0.244 & $0.423 n s$ & 0.143 \\
\hline & T2(20\%) & 5.4263 & -0.08 & $0.634-10.218$ & $-0.483-0.314$ & 0.173 & $0.171 n s$ & 0.029 \\
\hline & T3(25\%) & 3.4921 & 0.21 & $2.298-4.687$ & 0.119-0.306 & 0.040 & $0.881 * * *$ & 0.776 \\
\hline \multirow{3}{*}{$\mathbf{L Y M}=\mathbf{a}+\mathbf{b} \mathbf{T L}$} & T1(15\%) & 44.1734 & 1.55 & $-23.449-111.796$ & $-4.204-7.303$ & 2.495 & $0.214 n s$ & 0.046 \\
\hline & T2(20\%) & 102.7339 & -1.39 & $-1.396-142.724$ & $-4.519-1.727$ & 1.354 & $0.342 n s$ & 0.117 \\
\hline & T3(25\%) & 130.48 & -5.13 & 57.854-203.106 & $-11.166-0.907$ & 2.618 & $0.569 \mathrm{~ns}$ & 0.324 \\
\hline \multirow{3}{*}{$\mathbf{M O N}=\mathbf{a}+\mathbf{b} \mathbf{T L}$} & T1(15\%) & 0.5707 & 0.07 & $-1.099-2.240$ & $-0.073-0.211$ & 0.061 & $0.367 \mathrm{~ns}$ & 0.134 \\
\hline & T2(20\%) & 4.2398 & \begin{tabular}{|c|}
-0.11 \\
\end{tabular} & $-1.044-9.524$ & $-0.509-0.286$ & 0.172 & $0.223 n s$ & 0.049 \\
\hline & T3(25\%) & 3.1736 & -0.13 & $-0.176-6.524$ & $-0.413-0.143$ & 0.121 & $0.368 \mathrm{~ns}$ & 0.135 \\
\hline \multirow{3}{*}{$\mathbf{G R A}=\mathbf{a}+\mathbf{b} \mathbf{T L}$} & T1(15\%) & 8.9344 & -0.12 & $-16.770-34.639$ & $-2.303-2.071$ & 0.948 & $0.043 n s$ & 0.002 \\
\hline & T2(20\%) & 20.3043 & \begin{tabular}{l|l|}
-0.59 \\
\end{tabular} & $-9.332-49.941$ & $-2.821-1.636$ & 0.966 & $0.211 n s$ & 0.045 \\
\hline & T3(25\%) & 1.93879 & 0.21 & $-4.017-7.893$ & $-0.287-0.703$ & 0.215 & $0.324 n s$ & 0.105 \\
\hline \multirow{3}{*}{$\mathrm{MCV}=\mathbf{a}+\mathbf{b} \mathbf{T L}$} & T1(15\%) & 184.2326 & -2.98 & 74.119-294.345 & $-12.344-6.393$ & 4.063 & $0.251 \mathrm{~ns}$ & 0.063 \\
\hline & T2(20\%) & 216.5441 & \begin{tabular}{|l|}
-5.90 \\
\end{tabular} & 93.507-339.582 & $-15.154-3.348$ & 4.012 & $0.462 n s$ & 0.213 \\
\hline & T3(25\%) & 56.9642 & 5.24 & $-237.65-351.579$ & $-19.249--29.729$ & 10.619 & 0.172ns & 0.029 \\
\hline \multirow{3}{*}{$\mathbf{M C H}=\mathbf{a}+\mathbf{b} \mathbf{T L}$} & T1(15\%) & 30.1984 & 0.93 & $21.026-39.371$ & $0.146-1.708$ & 0.338 & $0.696 *$ & 0.484 \\
\hline & T2(20\%) & 44.6831 & -0.37 & 33.834-55.532 & $-1.221-0.473$ & 0.367 & $0.339 \mathrm{~ns}$ & 0.115 \\
\hline & T3(25\%) & 21.5133 & 3.18 & $-33.101-76.128$ & $-1.359-7.719$ & 1.968 & $0.496 \mathrm{~ns}$ & 0.246 \\
\hline \multirow{3}{*}{$\mathrm{MCHC}=\mathbf{a}+\mathbf{b} \mathbf{T L}$} & T1(15\%) & 10.4399 & 1.44 & $-22.296-43.176$ & $-1.344-4.226$ & 1.193 & $0.389 n s$ & 0.151 \\
\hline & T2(20\%) & 21.5592 & 0.58 & $-3.819-46.937$ & $-1.399-2.564$ & 0.859 & $0.233 n s$ & 0.054 \\
\hline & T3(25\%) & 103.2052 & -3.35 & $-86.900-293.311$ & $-19.151-12.451$ & 6.852 & $0.170 n s$ & 0.029 \\
\hline \multirow{3}{*}{$\mathbf{M P V}=\mathbf{a}+\mathbf{b} \mathbf{T L}$} & T1(15\%) & 5.3759 & 0.03 & $3.776748-6.975057$ & $-0.10701-0.165114$ & 0.059 & $0.171 n s$ & 0.029 \\
\hline & T2(20\%) & 34.6460 & 15.25 & $-126.557-195.8491$ & $2.660351-27.83789$ & 5.459 & $0.703 *$ & 0.494 \\
\hline & T3(25\%) & 4.1564 & 0.14 & $1.999941-6.3129$ & $-0.03668-0.321795$ & 0.078 & $0.544 n s$ & 0.296 \\
\hline
\end{tabular}

Correlation coefficient-r, coefficient of determination- $\mathrm{r}^{2}$, intercept-a, regression coefficient-b, Confidence intervals-Cl, standard error-S.E, ${ }^{* * *} \mathrm{P}<0.001, * * \mathrm{P}<0.01, * \mathrm{P}<0.05,{ }^{\text {ns }} \mathrm{P}>0.05$.

Table 3: Regression analysis and descriptive statistics of various haematologicalparameters in relation to weight (g) of GIFT Tilapia reared at graded levels of protein in hapas

\begin{tabular}{|c|c|c|c|c|c|c|c|c|}
\hline \multirow[b]{2}{*}{ Equation } & \multirow{2}{*}{$\begin{array}{c}\text { Diet } \\
\text { Variables }\end{array}$} & \multirow{2}{*}{\multicolumn{2}{|c|}{$\begin{array}{l}\text { Relationship } \\
\text { Parameters }\end{array}$}} & \multirow[b]{2}{*}{$95 \%$ CI of a } & \multirow[b]{2}{*}{$95 \%$ CI of b } & \multirow{2}{*}{$\begin{array}{l}\text { Standard } \\
\text { error }\end{array}$} & \multirow[b]{2}{*}{$\mathbf{r}$} & \multirow[b]{2}{*}{$\mathbf{r}^{2}$} \\
\hline & & & & & & & & \\
\hline \multirow{2}{*}{$\mathbf{P L T}=\mathbf{a}+\mathbf{b} \mathbf{W}$} & T1(15\%) & 280.5838 & -3.99 & 108.571- 452.597 & $-11.649-3.668$ & 3.321 & $0.391 n s$ & 0.153 \\
\hline & T3(25\%) & 173.3192 & 3.83 & $-106.509-453.148$ & $-4.229-11.888$ & 3.495 & $0.361 \mathrm{~ns}$ & 0.130 \\
\hline \multirow[b]{2}{*}{$\mathbf{W B C s}=\mathbf{a}+\mathbf{b} \mathbf{W}$} & T1(15\%) & 40.9895 & 0.75 & 13.719- 68.259 & $-0.465-1.963$ & $\mathbf{0 . 5 2 7}$ & $0.449 \mathrm{~ns}$ & 0.202 \\
\hline & T2(20\%) & 144.1648 & -1.50 & 87.325-201.004 & $-3.508-0.574$ & 0.885 & $0.506 n s$ & 0.256 \\
\hline \multirow[t]{2}{*}{$\mathbf{R B C s}=\mathbf{a}+\mathbf{b} \mathbf{W}$} & T2(20\%) & 1.0623 & 0.02 & 0.598- 1.527 & $0.032--0.002$ & 2.055 & $0.588 n s$ & 0.346 \\
\hline & T3(25\%) & 1.1639 & -0.01 & 0.733- 1.595 & $-0.020-0.005$ & 0.005 & $0.455 n s$ & 0.207 \\
\hline \multirow{3}{*}{$\mathbf{H G B}=\mathbf{a}+\mathbf{b} \mathbf{W}$} & T1(15\%) & 4.7768 & -0.01 & $3.208-6.346$ & $-0.057-0.033$ & 0.019 & $0.207 n s$ & 0.043 \\
\hline & T2(20\%) & 2.9032 & 0.10 & $-1.208-7.014$ & $-0.079-0.288$ & 0.079 & $0.419 n s$ & 0.176 \\
\hline & T3(25\%) & 4.2608 & 0.07 & $2.581-5.941$ & $0.009-0.130$ & 0.026 & $0.687^{*}$ & 0.472 \\
\hline $\mathbf{L Y M}=\mathbf{a}+\mathbf{b W}$ & T1(15\%) & 50.2545 & 0.55 & 8.471-92.039 & $-1.306-2.414$ & 0.807 & $0.236 \mathrm{~ns}$ & 0.056 \\
\hline $\mathbf{M O N}=\mathbf{a}+\mathbf{b} \mathbf{W}$ & T3(25\%) & 1.0416 & 3.19 & 1.042-3.189 & $-0.049-0.013$ & 0.013 & $0.427 \mathrm{~ns}$ & 0.182 \\
\hline GRA $=a+b$ W & T1(15\%) & 8.4217 & -0.04 & $-7.542-24.385$ & $-0.749-0.672$ & 0.308 & $0.044 n s$ & 0.002 \\
\hline
\end{tabular}




\begin{tabular}{|c|c|c|c|c|c|c|c|c|}
\hline & T2(20\%) & 4.6641 & 0.07 & -5.50914 .837 & $-0.290-0.440$ & 0.158 & $0.165 n s$ & 0.027 \\
\hline & T3(25\%) & 3.6728 & 0.02 & $1.713-5.633$ & $-0.032-0.081$ & 0.024 & 0.329 ns & 0.109 \\
\hline \multirow{3}{*}{$\mathrm{MCV}=\mathbf{a}+\mathbf{b W}$} & T1(15\%) & $\mathbf{1 7 7 . 5 4 3 7}$ & -1.29 & 111.031- 244.057 & $-4.261-1.662$ & 1.284 & $0.337 n s$ & 0.114 \\
\hline & T2(20\%) & 101.6689 & 0.67 & 56.095- 147.243 & $-0.970-2.303$ & 0.709 & $0.315 n s$ & 0.099 \\
\hline & T3(25\%) & 110.1940 & 0.29 & 11.932- 208.456 & $-2.534-3.125$ & 1.227 & $0.085 n s$ & 0.007 \\
\hline \multirow{3}{*}{$\mathbf{M C H}=\mathbf{a}+\mathbf{b W}$} & T1(15\%) & 34.7391 & 0.29 & $28.835-40.644$ & 0.552-0.027 & 0.114 & $0.668 *$ & 0.446 \\
\hline & T2(20\%) & 21.2995 & 0.28 & $-1.763-44.362$ & $-0.549-1.107$ & 0.359 & $0.264 n s$ & 0.069 \\
\hline & T3(25\%) & 46.1249 & 0.43 & 29.376- 62.874 & $-0.050-0.914$ & 0.209 & $0.589 n s$ & 0.348 \\
\hline \multirow{3}{*}{$\mathbf{M C H C}=\mathbf{a}+\mathbf{b W}$} & T1(15\%) & 15.1271 & 0.56 & $-4.40168-34.656$ & $-0.30853-1.430$ & 0.377 & $0.466 n s$ & 0.217 \\
\hline & T2(20\%) & 21.2996 & 0.28 & $-1.763-44.362$ & $-0.549-1.107$ & 0.359 & $0.264 n s$ & 0.069 \\
\hline & T3(25\%) & 67.9504 & -0.15 & $4.472-131.428$ & $-1.978-1.679$ & 0.793 & $0.066 n s$ & 0.004 \\
\hline \multirow{3}{*}{$\mathbf{M P V}=\mathbf{a}+\mathbf{b} \mathbf{W}$} & T1(15\%) & 5.4365 & 0.01 & $4.457-6.417$ & $-0.031-0.057$ & 0.019 & $0.235 n s$ & 0.055 \\
\hline & T2(20\%) & 4.8843 & 0.05 & 2.319- 7.449 & $-0.045-0.139$ & 0.039 & $0.386 n s$ & 0.149 \\
\hline & T3(25\%) & 5.3219 & 0.02 & $4.631-6.013$ & $-0.003-0.037$ & 0.009 & $0.579 n s$ & 0.335 \\
\hline
\end{tabular}

Correlation coefficient-r, coefficient of determination- ${ }^{2}$, intercept-a, regression coefficient-b, Confidence intervals-Cl, standard error-SE, $* * * \mathbf{P}<0.001, * * \mathbf{P}<0.01, * \mathbf{P}<0.05,{ }^{n} \mathbf{P}>0.05$

\section{DISCUSSION}

Haematological profile analysis of fishes is an integral part of evaluating their health status $[6,7,15]$. The values of haematological parameters observed in the present study are supported by findings of [9] in Cyprinus carpio, [21] reference interval values in hybrid tilapia and [22] in African catfish. [23] reported a nonsignificant correlation in various blood indices in Nile tilapia (Oreochromis niloticus) fed with synthetic feed with limited inclusion of fish oil. Nonsignificant increasing trend was observed for WBCs and lymphocytes with increasing level of $\% \mathrm{CP}$. The increased number of WBCs shows good health status of fish [6]. Higher number of WBCs in the studied fish is related to findings of $[9,15,24]$. Although, significantly higher WBCs count points at a possible immunomodulatory effect or due to stressor effect $[15,24]$. Reduced WBCs count may be attributed to stress imposed by handling the fish [9].[25] affirmed that lymphocytes are the most abundant leukocytes in fish followed by monocytes, neutrophils and eosinophils. Lymphocytes count $(\mathrm{T} 3=89.38 \pm 6.15)$ is supported by [6] worked out the effect of different protein energy ratios in juvenile Labeorohita $(90.08 \pm 6.51$ in $25 \% \mathrm{CP})$. Contrarily, [15] found low lymphocyte count in Nile tilapia fed with high levels of maltose $(35 \%)$. Monocytes showed the similar non-significant differences in all groups. Monocyte count are in agreement with findings of [15].[26] reported monocytes comprises less than $10 \%$ of the total WBCs in animals of all species.

In the present study, RBCs count revealed non- significant variations in $\mathrm{T} 1, \mathrm{~T} 2$ and $\mathrm{T} 3$ and corroborates [9, 22]. [9] stated high number of WBCs and RBCs shows good health status. Contrarily, $[3,27]$ noted low RBCs at high CP. Mostly the reduced RBCs count in fish may indicate the anemic status of fish under stressful conditions [28]. Hemoglobin, concentration 
gives reflection of oxygen supply of an organism and organism itself attempts to keep it as stable as possible [3]. An increasing trend of RBCs, HGB and HCT with increasing CP is in line with [16]. The levels of HGB and HCT are best related to [22]in African catfish. Red blood cell indices viz. $\mathrm{MCV}, \mathrm{MCH}$ and $\mathrm{MCHC}$ seem to be altered being more sensitive causing changing in the homeostatic system of fish [29]. Fish fed 15\% CP diet showed least significant result of $\mathrm{MCH}(\mathrm{P}<0.05)$ and non-significant $\mathrm{MCV}(20 \%, 25 \%)$ and $\mathrm{MCH}$ values $(15 \%, 20 \%$ and $25 \%)$ are related with $[3,21,22]$. $\mathrm{MCHC}$ is an indication of shrinkage or swelling of red blood cells [30]. In present study, T1 and $\mathrm{T} 2$ and $\mathrm{T} 3$ showed non-significant results $(\mathrm{P}>0.05)$ of $\mathrm{MCHC}$. The greater values of $\mathrm{MCHC}$ in the treated fish (T1) is probably an indication of RBCs shrinkage and/or reduced hemoglobin synthesis [3]. The most recognized role of platelets is to initiate blood clotting in the process of hemostasis. Platelet count is an indication of disease resistance and morbidity process of an organism [6]. An increasing trend of platelet level was exhibited. Least Significant $(\mathrm{P}<0.05)$ platelets against total length were noted in T2 while nonsignificant in $\mathrm{T} 1$ and $\mathrm{T} 3$. Platelets count against wet body weight in T1, T2 and T3 yielded non-significant correlation (Table 2 and 3).

\section{CONCLUSION}

In state of present investigation, it can be concluded that response of organisms varies with varying feed stuffs, and feed ingredients have pronounced influence on haematological profile of GIFT fingerlings. Protein level of $25 \%$ diet enhances the health status and physiological responses of treated fish.

\section{REFERENCES}

[1] Fotedar R, Effect of dietary protein and lipidsource on the growth, survival, condition indices and body composition of marron, Cheraxtenuimanus (Smith), Aquacult., 230, 2004, 439-455.

[2] NajimSM, Al-Noor SS, Jasim B M, Effects of fish meal replacement with fish biosilage on some haematological and biochemical parameters in common carp Cyprinus carpio fingerlings, Int. J. Res. Fish. Aquacult., 4(3), 2014, 112-116.

[3] Southamani C, Shanthi G, Deivasigamani M, Hematological response in three Indian major carps in relation to supplementary feeding, Int. J. Fish. Aquat. Stud., 3(2), 2015, 287-294. 
[4] Yones AMM, Metwalli AA, Effects of Fish meal substitution with poultry by-product meal on growth performance, nutrients utilization and blood contents of juvenile Nile Tilapia

(Oreochromis

niloticus), Aquaculture Research Development, 6, 2015, 389-394. doi:10.4172/2155-9546.1000389:1

[5] Habte-Tsion HM, Liu B, Ge X, Pan L, Chen R, Effects of dietary protein level on growth performance, muscle composition, blood composition, and digestive enzyme activity of wuchang bream (Megalobramaamblycephala) fry, Israeli Journal of Aquaculture Bamidgeh, 65, 2013, 925-933.

[6] Iqbal MJ, Naeem M,Haematological indices study of juvenile Labeorohita (Hamilton1822) fed at varying protein: Energy ratios, Int. J. Fish. Aquat. Stud., 4(5), 2016, 632-641.

[7] Martins M L, Mourino J L, Amaral GV, Vieira F N, Buglione-Neto C C, Pereira J G, Haematological and biochemical changes in Nile tilapia experimentally infected with Enterococcus sp, Braz. J. Biol., 3, 2008, 631-637.

[8] Moradi N, Imanpoor M, Taghizadeh $\mathrm{V}$, Hematological and biochemical changes induced by replacing fish meal with plant protein in the Cyprinus carpio Linnaeus (1785),Glob. Vet., 11, 2013, 233237.

[9] Nasir NA, Al-Sraji A Y J, Effect of Different dietary proteins and fats on some biochemical blood parameters in common carp fingerlings (Cyprinus carpio L.) reared in float cage, Asian J. exp. Biol. Sci., 4, 2013, 293-296.

[10] Svobodova Z, Machova J, Drastichova J, Groch L, Luskova V, Poleszczuk G, Velisek J, Kroupova H, Haematological and biochemical profiles of carp blood following nitrite exposure at different concentrations of chloride,Aquacult. Res., 36, 2005, 1177-1184.

[11] Haider MJ, Valeem EE, Saleem T, Wahid SH, Shafiq M, Talat R, MajeedY, Effect of algal formulated diet on the haematology of Labeorohita Hamilton-Buchanan, Int. J. Phycol. Phycochem., 7(2), 2011, 163-170.

[12] Anyanwu DC, Udedibie ABI, Osuigwe DI, Ogwo VO, Haematological responses of hybrid of Heterobranchus 
bidorsalis and Clariasgarie pinus

fed dietarylevels of Carica papaya leaf meal, W. Rural Observ.,3, 2011, 9-12.

[13] Anyanwua DC, Udedibieb ABI, Osuigweb DI, Offora JI, Onogu B,Haematological responses of Heteroclarias fed dietary levels of Alchornia cordifolia leaf meal, Int. J. Res. Pharm. Biol. Sci., 2, 2015, 11-15.

[14] Naveen AP, Venkaeshwaslu J C, Biochemical alteration induced by triazophos in the blood plasma of fish Channa punctatus (Bloch.), Annals Biol. Res.,2(4), 2011, 3137.

[15] Ighwela K A, Ahmad AZ, AbolMunafi AB, Haematological changes in nile tilapia (Oreochromis niloticus) fed with varying dietary maltose levels, World J. Fish. Mar. Sci.,4, 2012, 376-381.

[16] Khan IA, Maqbool A, Effects of dietary protein levels on the growth, feed utilization and haemato-biochemical parameters of freshwater fish, Cyprinus carpioVar. Specularis, Fish Aqua. J., 8, 2017, 187-198.

[17] Datta S N, Singh A, Mandal A, Jassal G, Effect of different dietary protein sources on hematological parameters of striped catfish Pangasianodon hypophthalmu, Journal of Entomology and Zoology Studies, 6(2), 2018, 31983202.

[18] Osuigwe D I, Nwosu C,Ogunji J O, Preliminary observations on some haematological parameters of juvenile Heterobranchus longifilis fed different dietary levels of raw and bioledjackbean (Canavalia ensiformis) seed meal, In: Proceedings of Conference of International Agricultural Research Development, Tropentag, University of KasselWitzenhausen and University of Göttingen, 2007, 6.

[19] Fernandes MN, Mazon AF, Environmental Pollution and Fish Gill Morphology, In: Val, AL, Kapoor, BG, Eds., Fish Adaptation, Science Publishers, Enfiel, 2003, 203-231.

[20] Omotayo F, Ayo I.O, Fisayo A D, Hematological and serum biochemical profile of Nile tilapia, Oreochromis niloticus from Ero Dam in Ikun Ekiti, Ekiti State Nigeria, Amri. J. Res. Commun., 4(4), 2007, 200-205. 
[21] Hrubec TC, Cardinale J L, Smith SA, Hematology and plasma chemistry reference intervals for cultured tilapia (Oreochromis hybrid), Vet. Clin. Pathol., 29, 2000, 7-12.

[22] Ochang SN, Fagbenro OA, Adebayo OT, Growth performance, body composition, haematology and product quality of the African catfish (Clariasgarie pinus) fed with palm oil, Pak. J. Nut.,6 (5),2007, 452459.

[23] El-Kasheif MA, Amal SS, Seham A,Effects of varying levels of fish oil on growth performance, body composition and haematological characteristics of Nile tilapia (Oreochromis niloticus L), Egypt. J. aquat. Biol. Fish., 15, 2011, 125-141.

[24] Martins M L, Moraes F R, Fujimoto RY, Nomura D T, Fenerick Jr J, Responses of the tambacu hybrid (Piaracusmesopotamicus

Holmberg, 1887 male $\mathrm{x}$ Colossomamacropomum Cuvier, 1818 female) to simple or consecutive capture stimuli, Bol. Inst. Pesca., 28(20), 2000, 195204.
[25] Hrubec $\mathrm{T}$ C, Smith $\mathrm{S}$ A, Hematology of fishe, In: Weiss D J, Wardrop K J, (Eds.), Schalm's veterinary hematology, 6th ed, Ames Iowa Wiley-Blackwell, 2010, 994-1003.

[26] Kelly W R, Vet. Clinical Diagnosis, (2nd edition), Balliere Tindall, London, 1979.

[27] Yue YR, Zhou Q C, Effect of replacing soybean meal with cottonseed meal on growth, feed utilization, and hematological indices for juvenile hybrid tilapia (Oreochromis niloticus), Aquacult., 284, 2008, 185-189.

[28] Li Z, Velisek H, Zlabek J, Grabic R, Machova R J, Kolarova J, Chronic Toxicity of Verapamil on Juvenile Rainbow Trout (Oncorhynchus mykiss): Effects on iorphological Indices, hematological parameters and antioxidant responses, J. Hazard. Mater., 185, 2011, 870-880.

[29] Ahmed Z, Acute toxicity and haematological changes in common carp (Cyprinus carpio) caused by diazinon exposure, African J. Biotech., 10(63), 2011, 13852-13859.

[30] Wepener V, Van Vuren J H J, Du Preez H H, Effect of manganese 
and iron at neutral and acidic $\mathrm{pH}$

on the haematology of the banded

tilapia (Tilapia sparrmanii),Bull.

Environ. Cotam. Toxicol., 49, 1992, 613-619. 